\title{
Education Post Covid-19 Pandemic: Build Partnerships to Strengthen Quality and Competitiveness of Higher Education in Indonesia
}

\author{
Marselus Ruben Payong ${ }^{1}$, Kristianus Viktor Pantaleon ${ }^{2}$ \\ Universitas Katolik Indonesia Santu Paulus Ruteng \\ \{marselpayong@yahoo.com $\left.{ }^{1}\right\}$
}

\begin{abstract}
Covid-19 has emerged a new era in education with various challenges, problems, and opportunities. To deal with these changes, the education institutions, including universities, cannot fight alone but must build cooperation. Cooperation with the government, business and industry will enable universities to adapt to technological developments and the demands of the work employment. This article is a literature study. The data and information are obtained from secondary sources, especially the results of research and government publications related to the condition of universities in Indonesia. Data were analyzed using qualitative descriptive analysis. The results of the review show that the triple helix collaboration (HE, government, and business and industry sectors) will positively impact the readiness of graduates to work and increase student learning activities outside the campus. This collaboration also increases lecturer activities outside campus (education, research, and community service), improve their both qualifications and also their publications' productivity and quality. Overall, it will impact the quality of higher education (accreditation status and institutions rank). authority.
\end{abstract}

Keywords: higher education (HE); government; business and industry sectors (BIS); triple helix

\section{Introduction}

The Covid-19 pandemic has brought up new things, both challenges/problems, and opportunities. The implementation of primary, secondary and higher education is also affected by this outbreak. Everyday activities in school and college such as face-to-face learning, classroom-based learning, scientific meetings with many participants are now being replaced by technology. Most of the learning is done online, both synchronously and asynchronously. Learning from home (LFH) is a new trend in today's education.

Some studies on the impact of the Covid-19 pandemic have shown mixed results. Studies show that the Covid-19 pandemic has created a new need for learning to media, primarily through computers and the internet $[1,2,3]$. However, because not all students have access to computer facilities and internet networks, the expected learning outcomes are often not following the demands of the curriculum, causing gaps in the quality of learning outcomes. The most severe problems occur in elementary schools where essential literacy learning: reading, writing and arithmetic (calistung) for lower grade students is neglected or not run properly.

The Covid-19 pandemic emerged when the world was hit by the Industrial Revolution 4.0. This industrial revolution was marked by the birth of a new phenomenon, namely disruption 
[4]. Disruption in a particular system or institution is caused by the emergence of a particular innovation or technology. That is why it is often called disruptive innovation or disruptive technology [5]. For Christensen, the characteristics of disruptive innovation are characterized by four main things, namely that innovation is: cheaper, simpler, smaller and more convenient than competitors or old technology.

Every innovation always gives birth to a particular dilemma because there will be benefits and disadvantages almost simultaneously [5]. On the one hand, innovation or technology will give birth to efficiency and effectiveness in specific jobs. However, at the same time, it can destroy or eliminate previous work patterns and structures to impact reducing the workforce. The dilemma of this innovation emerged a long time ago when technological equipment replaced human labour. However, compared to technological discoveries in the 18th and 19th centuries, technology in the 20th and 21 st centuries, especially computer technology, has caused very radical changes in various fields of life. At first, the disruption hit traditional business institutions but then slowly eroded other institutions, including education.

How is the implementation of education after the Covid-19 pandemic? Will there be transformation and disruption in its implementation? How is the quality and competitiveness of education, and what new order can emerge when a new way of life is born in this new era? This paper will focus on implementing higher education after the Covid-19 pandemic and improving its quality and competitiveness. This paper wants to show that it is time for universities to open up to establish partnerships and collaborations with higher education institutions and other institutions to strengthen the resilience of their institutions, especially in the face of such disruptive waves of change.

\section{Research Methods}

This is a literature study that uses the triple helix model. The data is obtained from secondary sources, especially the results of research and government publications related to the condition of universities in Indonesia. Main data for analysis come from current Indonesia's Higher Education Rank and published by Ministry of Education and Culture (2020) and Indonesia Higher Education Database (Pangkalan Data Perguruan Tinggi - PD Dikti). Data were analysed using qualitative descriptive analysis.

\section{Results and Discussion}

The development of higher education in Indonesia over the last decade shows an interesting phenomenon. Gardiner et al. [6] quantitatively noted a relatively constant growth in the institutional aspects of higher education, students, and lecturers. During the period 2008 2014, the development of higher education showed an average growth rate as follows: 1) the development of the number of higher education institutions increased by $3.41 \%$; 2 ) the number of students has increased by $5.98 \%$, and 3) the number of lecturers has increased by $1.75 \%$ [7]

The number of students can be seen in the higher education Gross Enrollment Rate (GRE). The GRE in 2019 is $34.58 \%$, which shows that $34.58 \%$ of the Indonesian population aged 1824 years are currently studying in higher education. This figure increased by $5.43 \%$ compared to the GRE in 2013, 29.15\% (Center for Education Data and Statistics of the Ministry of Education and Culture, 2014) [7]. Data from Indonesia Higher Education Database (Pangkalan 
Data Perguruan Tinggi - PD Dikti) [8] shows the number of students in the 2019 is 8,764,506 people. Interestingly, 1,045,667 (11.93\%) are Open University students, while the rest are students at regular universities. The development of the number of students at the Open University can indicate the disruption of higher education in Indonesia because the increase in the number of students follows the exponential development of the disruption. The data show that in 2001, the number of Open University students was 165,222. This figure almost quadrupled in $2011(578,698)$ [9] and almost doubled again in $2021(1,045,667)$.

This quantitative development has not shown a significant impact on the quality and competitiveness of universities nationally and internationally. Based on world university ranking data, no university in Indonesia is included in the WCU category with a below 500 . Nationally, the ranking of universities conducted by the government also shows that most universities are low performing, especially in clusters 3-5. The data shows that of the 4,615 universities in Indonesia, 1,590 universities (34.45\%) of them are in cluster 5 (score $0.000-$ $0.999)$ and 400 universities $(8.67 \%$ ) are in cluster 4 (scores $1,000-1,498)$ and 97 universities $(2.1 \%)$ are in cluster 3 (score $1.512-1.996)$ [10]. So overall, there are still around $45.22 \%$ of low performing universities.

In the cluster 1 and cluster 2 Indonesia University Rank, it seems that they are still dominated by high quality public and private universities, which have adequate resources and excellent status of higher education accreditation. Higher education warning programs and higher education accreditations that have been implemented so far have not fully impacted the overall performance, quality and competitiveness of higher education institutions. Changes in terms of increasing accreditation status, for example, do not entirely reflect the actual quality of higher education.

Data on the quality and competitiveness of higher education institutions in Indonesia, as seen from the clustering of higher education rankings released by the Ministry of Education and Culture every year, shows that not all universities have the same quality and competitiveness. There is a prominent disparity, especially between public and private universities and between universities in various regions/regions. This condition occurs because all universities struggle individually to use all possible limited resources to meet the standards that have been set. Individual struggles faced with high competition will cause universities with substantial resources to stand out.

Otherwise, universities with limited resources will stumble. This condition is also one of the evaluations of implementing higher education accreditation by the National Accreditation Board for Higher Education (Badan Akrediasi Nasional Perguruan Tingi - BAN PT) for approximately two decades. The evaluation results show that after accreditation and reaccreditation of tertiary institutions and study programs at tertiary institutions, it appears that those who are superior remain superior. Those who are weak continue to walk in place or progress limply and are still far from superior.

\section{Context and Strategic Issues Education Development Direction 2020-2024}

The Ministry of Education and Culture, when formulating the Strategic Plan of the Ministry of Education and Culture 2020-2024 [11], has considered the wave of disruption that is currently hitting. The Ministry of Education and Culture's Strategic Plan, 2020-2024, emphasizes that human resource development, will take global trends into account. Human resource development must consider rapid technological advances, socio-cultural shifts, environmental changes, and differences in the future of work in education at every level and field.

First, technological advances that drive the Industrial Revolution 4.0 and the accompanying breakthroughs affect all sectors of life. Around the world and in all industries, 
automation, artificial intelligence, big data, and 3D printing are applied. Connectivity between people is also increasing, facilitated by technology, such as $5 \mathrm{G}$ connectivity that allows the emergence of autonomous vehicles (autonomous vehicles) and drone delivery.

Second, there is a shift in the demographics and socio-economic profile of the world's population socio-culturally. More and more people are living longer and therefore able to work longer hours. Developing countries will experience increased migration, urbanization, cultural diversity, and the number of middle classes. The workforce will have greater flexibility and mobility, thus blurring the boundaries between work and everyday life. Consumers will be increasingly concerned about ethical, privacy, and health issues.

Third, the need for energy and water will continue to rise in the environmental field, while natural resources will be depleted in 20 (twenty) years. The use of alternative energy or clean energy will increase to counter climate change and pollution. Efforts are made to maintain environmental sustainability and overcome various environmental problems will also be more extraordinary.

Fourth, the world of work in the future will be very different from what it is today. The three significant changes mentioned earlier shaped the work world that differed in structure, technology, and self-actualization concepts. The work structure will be more flexible, know no geographical boundaries and not be bound so that workers will not be tied to just one institution throughout their careers. Freelance and temporary workers will overgrow. Workers of all ages can work together because life expectancy is getting longer, demanding respect for diverse backgrounds. Technology makes daily work more accessible, but it also demands the mastery of new skills and knowledge. The future workforce is also better able to control their careers and seek personal satisfaction in their work.

In order to be successful in the future work environment and global challenges, the Ministry of Education and Culture has determined 6 (six) Pancasila student profiles that must be cultivated in current students, namely: (1) global diversity, (2) cooperation, (3) creative, (4) critical reasoning, (5) independent, and (6) faith, fear of God Almighty, and noble character.

\section{Development and Convergence of Science and Technology}

Science and technology are some drivers of the dynamics and development of society and the world of work. Science has developed so rapidly so that it is often unpredictable in advance [12]. The Industrial Revolution 4.0 (IR 4.0) currently provides challenges and opportunities for future economic development. On the one hand, digitization, automation, and artificial intelligence in economic activities will increase productivity and efficiency in modern production and provide convenience for consumers. Digital technology also helps the development process in various fields, including education through distance learning, government through e-government, financial inclusion through financial technology (fin-tech), and the development of Micro, Small and Midle Enterprises (MSMEs) along with the development of e-commerce.

However, on the other hand, the development of industrial revolution 4.0 can cause the loss of many jobs in the world. It is estimated that 60 per cent of job titles in the world will be replaced by automation. The development of science has also shown convergence or marriage between the fields of science, especially between pure science and applied science/engineering, between science and social science.

The rapid development of science and technology has also brought about a new era called disruption. The era of disruption is "chaos" to various institutions due to extraordinary developments in technology, especially information and communication technology. This era gave birth to digitalization, big data, interconnectivity, automation, and artificial intelligence. 
The old order and institutions experienced shocks and chaos due to the emergence of a new order that put forward the principles of efficiency, effectiveness, transparency, and speed. At first, this phenomenon had an impact on business and manufacturing organizations. The presence of e-commerce, for example, has changed the traditional trade order [4].

This disruption has also eroded the educational order with online learning, mass open online courses (MOOC) that do not require lecture halls, teachers/lecturers, and formal educational institutions. All knowledge and skills are readily available through the internet and can be accessed/learned anywhere and anytime $[6,13,14,15]$. The disruption phenomenon is an opportunity and a threat to all formal educational institutions, especially universities. Many skills and expertise are available in big data networks and can be accessed via the internet anytime and anywhere. In that case, the need to continue education to secondary or tertiary levels such as universities could one day be threatened. On the other hand, online learning can also be an opportunity for universities to provide services to the community that can be accessed anytime and anywhere.

\section{Regional Development and Mid-Term Development Directions 2020-2024}

The sustainable development agenda is implemented in various countries through mapping the area for equity and growth. Equity is aimed at specific areas that are still lagging in economic development so that they require serious attention from both the government and all elements of society, including universities. Equitable development is primarily to address several crucial issues such as poverty, health and food security.

According to Presidential Regulation No. 32 of 2011 concerning the Master Plan for the Acceleration and Expansion of Indonesian Economic Development (MP3EI) 2011-2025, there are three main strategies for accelerating and expanding national economic development towards Indonesia 2025, namely: 1) Development of Economic Potential Through Economic Corridors, 2) Strengthening National Connectivity, and 3) Development of Human Resources and National Science and Technology Capability [16].

The role of higher education is one of the pillars in supporting the third strategy, namely increasing the capacity of human resources and national science and technology. Human resources are one of the crucial factors driving the economy and social change. In the era of a knowledge-based economy, the engine of economic growth relies heavily on the capitalization of inventions and innovative products. Therefore, the role of academic human resources is the primary key in supporting sustainable economic growth. Therefore, the main goal in the education and training system to support the above must be to create human resources that can adapt quickly to the development of science and technology.

Productive and adaptive human resources are produced through quality education that is relevant to development needs. In an economy that is increasingly shifting towards a knowledge-based economy, the role of higher education is vital. Higher education produces a superior and productive workforce, who can increasingly apply the required science and technology to increase the added value of sustainable economic activities. Higher education here consists of academic education programs, vocational education programs, and professional education programs.

The development of academic education programs is directed at aligning fields and study programs with the potential for economic development in each economic corridor. The academic program must be a network that fills and develops the added value chain of each commodity or sector developed in each economic corridor. Research centre universities are developed nationally as an essential part of the national innovation centre. The development of 
research centre universities is based on integration, resource sharing, and optimal use of information technology [17].

Meanwhile, Presidential Decree No. 18 of 2020 concerning the National Medium-Term Development Plan 2020-2024 stipulates improving the quality of human beings as one of its primary missions, with one of its strategies being to increase productivity and competitiveness of universities [18]. The government has programmed to strengthen higher education to play a role as a producer of science and technology innovation and a centre of excellence. The program includes strengthening the focus of the field of science according to the potential of the local area and increasing research consortium cooperation between universities and between universities and research institutions at home and abroad. Cooperation between universities, industry and the government can allow universities and industry to interact intensively and conduct research and development that is more beneficial to the community. In addition, this collaboration can facilitate the mobility of researchers between universities and industries.

Improving the quality of higher education graduates needs to be developed by developing quality and adaptive study programs. Study programs need to design learning curricula that are in line with the needs of industrial and regional development, expansion of certification, programs for accelerating work waiting periods, and entrepreneurship training to encourage the growth of young entrepreneurs. Universities are also encouraged to carry out three university missions: a research university, teaching university, or vocational university.

\section{Learning Independent and Independent Campus}

Learning Independent and Independent Campus (Merdeka Belajar, Kampus Merdeka = MBKM) is a strategic program of the Ministry of Education and Culture in the era of Minister Nadiem Makarim. Through this program, the management and process of education in HE are flexible in implementing the three mission of HE (teaching and education, research, and community service)[19]. Through the MBKM policy, 1) granting autonomy to public/private universities accredited A/B and collaborating with WCU to open new study programs to respond to local needs. Also, universities can collaborate with various parties, especially the business and industrial sectors (BIS), to develop curriculum, work practices/internships, work placements at BIS. Students can take courses from other universities. 2) Automatic reaccreditation program for all ranks and voluntary for universities and study programs ready to advance in rank. The accreditation status that BAN-PT has determined remains valid for five years but will be renewed automatically. Accreditation status will be reviewed if there are complaints from the public, a decrease in the number of students and the number of graduates constantly. 3) MBKM gives the freedom to Public Universities (PTN) as Public Service Agency (Badan Layanan Umum - BLU) and Work Unit (Satuan kerja - Satker) to become PTN Legal Entity (PTN BH) without being bound by accreditation status. Furthermore, 4) give students the right to take courses outside the study program in the same university or at other universities. With that, there is also a change in the definition of credit earning. Taking off-campus courses is a maximum of two semesters or the equivalent of 40 credits.

Taking credit outside the study program / higher education can be done with several forms of activities such as 1) internships/work practices in the BIS, non-profit institutions, 2) projects in the village in the form of community service for community empowerment in rural areas or remote areas, 3) teaching in schools, 4) student exchanges where students can take classes or semesters at other universities both at home and abroad based on cooperation agreements between universities, 5) research/research carried out under the supervision or guidance of lecturers or researchers, 6) entrepreneurial activities, where students develop entrepreneurial activities independently outside campus, 7) independent studies or projects, namely students 
develop projects that are initiated independently or jointly to participate in international competitions that are relevant to their scientific fields, 8) humanitarian projects, namely social activities or community service carried out by universities and humanitarian organizations at home and abroad, such as natural disaster management, community empowerment, environmental rescue, red cross, and peace corps.

The MBKM idea also marks a critical disruption in the implementation of higher education, especially the implementation of the three missions of Higher Education. Previously, the implementation of the three missions, especially education and teaching, was classroombased, campus-based. In MBKM, learning can also be carried out outside campus, in the community, or in other institutions whose credits can be recognized. Even if the implementation of the three missions was previously carried out separately for the three fields, then through MBKM, its implementation can be synergized. In MBKM, students can attend lectures through research activities or community service.

\section{Triple-Helix Partnership as a Model for Advancement and Competition}

In developing and improving the quality of higher education, cooperation is inevitable and is a strategic opportunity to improve the quality and competitiveness of higher education. This collaboration can be done at least with three strategic partners (often also called the triple-helix) [20], namely: cooperation with leading universities, cooperation with the government/local government, and cooperation with the business and industry sector (BIS).

The involvement of BIS in the above cooperation partners is closely related to the Higher Education Key Performance Indicators (Indikator Kinerja Utama Perguruan Tinggi - IKU PT), which are stipulated through the Decree of the Minister of Education and Culture Number 754/P/ 2020 [21]. In the Ministry of Education and Culture, the partnership between universities and BIS can be seen in input, process, output, and even outcome aspects.

\section{Cooperation with Leading Universities or Overseas Universities}

Cooperation with leading universities is the most strategic and most likely step at this time. Through this collaboration, many other programs can be implemented under the framework of cooperation to improve the quality of the tri dharma, which can boost scores on the components of input, process, and output and outcome. Through collaboration with leading universities or foreign universities, the results that can be obtained and their impacts are as follows:

Table 1. Benefits and Impacts of Cooperation with World Class University.

\begin{tabular}{|c|c|}
\hline Benefits & Impacts \\
\hline $\begin{array}{l}\text { - The opportunity of attending doctoral degree } \\
\text { for lecturers with scholarships scheme } \\
\text { (BPPS/BPPDN scholarship scheme) } \\
\text { - The opportunity for visiting lecturer/visiting } \\
\text { professor/visiting scholar } \\
\text { - The opportunity for assistance in the } \\
\text { development of new study programs } \\
\text { The opportunities for students to take course } \\
\text { outside of HE institutions (free learning). } \\
\text { The entrance to cooperation with BIS } \\
\text { - The entrance to cooperation with } \\
\text { overseas university / WCU }\end{array}$ & $\begin{array}{l}\text { - } \begin{array}{l}\text { An increasing number of doctoral lecturers } \\
\text { - }\end{array} \text { An increasing number of research and } \\
\text { scientific publications (especially indexed } \\
\text { international publications) } \\
\text { - An increasing number of associate professor } \\
\text { and professor } \\
\text { - Increasing the number of students taking } \\
\text { courses at outside HE institutions } \\
\text { - New study programs added } \\
\text { - } \quad \text { Increasing the level of study programs (S1 to } \\
\text { S2 / S2 to S3) } \\
\text { Increasing the number of proposals that get } \\
\text { grants from government or external } \\
\text { institutions }\end{array}$ \\
\hline
\end{tabular}




\begin{tabular}{|c|c|}
\hline Benefits & Impacts \\
\hline $\begin{array}{l}\text { - The opportunity to increase study program } \\
\text { qualification level (from undergraduate to } \\
\text { graduate programs.) } \\
\text { The opportunity to get reviewers of research } \\
\text { proposals, community service proposals, or } \\
\text { journals. } \\
\text { The opportunities for quality benchmarking } \\
\text { in order to improve the accreditation status } \\
\text { of institutions or study programs }\end{array}$ & $\begin{array}{l}\text { The scientific journals owned by the HE } \\
\text { can increase their accreditation status (e.g. } \\
\text { from Sinta } 5 \text { to } 4 \text { or from Sinta } 3 \text { to Sinta } \\
\text { 2). } \\
\text { Increasing the accreditation status of study } \\
\text { programs/PT }\end{array}$ \\
\hline
\end{tabular}

\section{Cooperation with the Business and Industry Sectors (BIS)}

The BIS is also a strategic partner in the development of higher education. The Ministry of Education and Culture stipulates that partnerships with the business and industrial sectors are an assessment component in ranking higher education institutions in input, process, output, and outcome. In the input component, the business and industrial sectors become partners where lecturers can do internships or have practical experience. In the process component, the business and industrial sectors are also the places for lecturers and students to practice, do internships, or carry out case-based, project-based or factory teaching lectures, conduct research with practicalbased problems. Thus, the innovations produced by universities are genuinely in accordance with the needs of BIS and can be used to increase their productivity.

Partnership cooperation with BIS can also strengthen institutional resilience, especially in terms of funding. Through patents from innovations produced by universities, BIS can use it, and the proceeds from the purchase of patents or products can also increase the universities' income. Several leading universities in Indonesia that collaborate with BIS get benefits in funding for research and development and for learning activities through Corporate Social Responsibility (CSR) funds provided by BIS. Cooperation with BIS can be done directly with BIS or through other leading universities that have cooperation with BIS.

Table 2. Benefits and Impacts of Cooperation with BIS.

\begin{tabular}{|c|c|}
\hline Benefits & Impacts \\
\hline $\begin{array}{l}\text { - There are opportunities for lecturers and students } \\
\text { for internships (for case-based, project-based, } \\
\text { teaching factory models). } \\
\text { The opportunities to conduct research and } \\
\text { development (R\&D) are available } \\
\text { There are opportunities for BIS practitioners to } \\
\text { teach at HE } \\
\text { There are job opportunities for graduates } \\
\text { - The opportunity to obtain funding sources, } \\
\text { especially for research and community service. } \\
\text { Opportunity for lecturers to obtain competency } \\
\text { certificates recognized by BIS }\end{array}$ & $\begin{array}{l}\text { - Increasing the number of students and } \\
\text { lecturers who do internships or conduct } \\
\text { the study case-based, project-based, } \\
\text { teaching factories (off-campus lectures) } \\
\text { - Increasing the number of practitioners } \\
\text { as lecturers } \\
\text { Increased research, community service } \\
\text { and scientific publications for lecturers } \\
\text { with BIS locus } \\
\text { Increasing the number of funds for } \\
\text { research and community service } \\
\text { financing by donations/CSR. } \\
\text { Increasing the number of lecturers who } \\
\text { get competency certificates recognized } \\
\text { by BIS } \\
\text { Addition of facilities/ infrastructures }\end{array}$ \\
\hline
\end{tabular}




\section{Cooperation with the Government (National and Local)}

The third partnership can be done with the government through specific ministries or government agencies, or local governments. The government indeed expects the participation of universities in overcoming development problems both nationally and regionally. In the National Medium-Term Development Plan, 2020 - 2025, the Indonesia Government has mapped many issues, especially regional issues and potentials, that require intervention to overcome poverty, increase economic growth, and increase equitable growth development throughout the region. Universities can contribute by providing solutions to these development problems by providing innovations to increase the economic growth. Through this collaboration, universities can offer product innovations, policies, problem-solving models, technical assistance and advocacy for community groups in need. Cooperation with the government / local government can also open up opportunities for universities to enter the business and industrial sectors (BIS).

BAN-PT had released the new instruments IAPT 3.0 (for institutional higher education accreditation) and IAPS 4.0 (for study programs accreditation) that stipulated nine assessment criteria: 1) vision, mission, goals and strategies; 2) governance, governance and cooperation; 3 ) students; 4) human resources; 5) finance, facilities and infrastructure; 6) education; 7) research; 8) community service; 9) outcomes and achievements of the teaching, research and community service. What is interesting about these nine criteria is that they were compared with the criteria in the old instrument, namely, the shift in "cooperation" from Standard 7 (Research, Community Service, and Cooperation) to criterion 2 (Governance, Governance, and Cooperation). Specifically, about cooperation, it appears that the activities should be carried out institutionally and at least includes teaching, research, and community service). Previously, cooperation was often only seen from formal documents such as a memorandum of understanding (MoU) and a memorandum of action (MoA). In the new instrument, cooperation must be visible and operational through concrete activities. The effectiveness of this collaboration is measured through partner satisfaction and its impact on improving the quality of the university's tri dharma implementation process (teaching, research, and community service). Such demands make all universities look for cooperation partners if they want an excellent accreditation score.

Table 3. Benefits and Impacts of Cooperation with the Government/Local Government.

\begin{tabular}{|c|c|}
\hline Benefits & Impacts \\
\hline $\begin{array}{l}\text { - Opportunities for the implementation of the } \\
\text { three mission of HE, mainly research and } \\
\text { community service and independent learning } \\
\text { There are opportunities for assistance, } \\
\text { advocacy, consulting to particular } \\
\text { communities (free to learn) } \\
\text { - Opportunity to get financing sources } \\
\text { - Entrance for BIS }\end{array}$ & 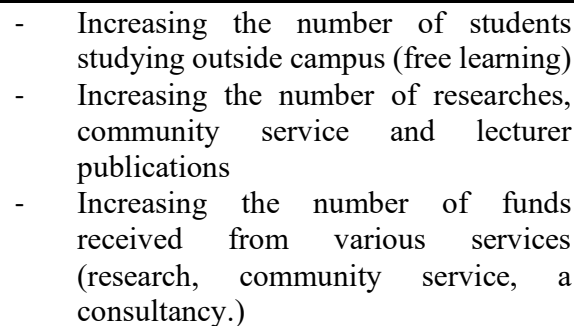 \\
\hline
\end{tabular}

\section{Conclusion}

From some of the descriptions above, partnership and cooperation are vital factors, especially for robust, healthy, and competitive universities. Partnerships require a willingness to learn and share. Disruption has destroyed the barriers of college egoism so that the resources 
and wealth owned by each university can be shared and utilized by other parties. The partnership opens opportunities for universities to develop and increase the strength of their resources by utilizing the potentials and strengths of partners.

In this highly disruptive era, the boundary between "friend" and "foe" is becoming unclear, so that the spirit of rivalry and single fighter is irrelevant.

\section{References}

[1] Asmuni (2020), Problematika Pembelajaran Daring di Masa Pandemi Covid-19 dan Solusi Pemecahannya. Jurnal Paedagogy, 7(4). doi:https://doi.org/10.33394/jp.v7i4.2941

[2] Kurniasari, A., Pribowo, F.S.P., \& Putra, D.A., (2020), Analisis Efektivitas Pelaksanaan Belajar dari Rumah (BDR) Selama Pandemi Covid-19; Jurnal Review Pendidikan Dasar, Vol. 6 No. 3, September 2020.

[3] Abidah, A., Hidaayahtullaah, H.N., Simamora, R.M., Fehabutar, D., \& Mutakinati, I., (2020), The Impact of Covid-19 to Indonesian Education and Its Relation to the Philosophy of "Merdeka Belajar", Studies in Philosophy of Science and Education (SiPoSE), Vol. 1 No. 1, April 2020, pp. 38-49.

[4] Schwab, K. (2016), The Fourth Industrial Revolution, Geneva: World Economic Forum.

[5] Christensen, C.M., (1997), The Innovator's Dilemma, When New Technologies Cause Great Firms to Fail, New York: Harvard Business School Publishing.

[6] Gardiner, Mayling-Oey, dkk., (2017), Era Disrupsi, Peluang dan Tantangan Pendidikan Tinggi Indonesia, Jakarta: Akademi Ilmu Pengetahuan Indonesia (AIPI).

[7] Pusat Data dan Statistik Pendidikan, Kemdikbud (2014), APK PAUD, SD, SMP, SM, PT Tahun 2013/2014, Jakarta: Kemdikbud.

[8] Pangkalan Data Perguruan Tinggi (PDDikti)(2021), https://pddikti.kemdikbud.go.id/

[9] Puspitasari, K.A., et.al. (2016), Empat Windu Membangun Negeriku, 32 Tahun Universitas Terbuka, Jakarta: UT.

[10] http://klusterisasi-pt.kemdikbud.go.id/

[11] Kemdikbud, (2020), Rencana Strategis Kemdikbud 2020-2024, Jakarta: Kementerian Pendidikan dan Kebudayaan.

[12] [12] Gleason, Nancy W., (2018), Higher Education in the Era of the Fourth Industrial Revolution, Singapore: Palgrave-McMillan.

[13] Flavin, M. (2017), Disruptive Technology, Enhanced Learning, The Use and Misuse of Digital Technologie in Higher Education, London: Palgrave-MacMillan.

[14] Picciano, A.G. (2019), Online Education, Foundations, Planning, and Pedagogy, London: Routledge.

[15] Payong, M.R., (2020), "Pembelajaran Daring Di Era Pandemik Covid-19 Menakar Kesiapan, Menatap Tantangan", dalam Regus, M. \& Yuliantari, A.P., (ed.), Bunga Rampai Tantangan Pendidikan di Masa Pandemi, Ruteng: Unika Santu Paulus.

[16] Peraturan Presiden No. 32 tahun 2011 tentang Masterplan Percepatan dan Perluasan Pembanguan Ekonomi Indonesia (MP3EI).

[17] Zuhal, (2010), Knowledge and Innovation, Platform Kekuatan Daya Saing, Jakarta: PT. Gramedia Pustaka Utama.

[18] Peraturan Presiden No. 18 tahun 2020 tentang Rencana Pembangunan Jangka Menengah Nasional 2020-2024.

[19] "Mendikbud Luncurkan Empat Kebijakan Merdeka Belajar dan Kampus Merdeka" (https://www.kemdikbud.go.id/main/blog/2020/01/mendik bud-luncurkan-empat-kebijakanmerdeka-belajar-kampus-merdeka

[20] Etzkowitz, Henry, (2008), The Triple Helix, University-Industry-Government Innovation in Action, London: Routledge.

[21] Keputusan Menteri Pendidikan dan Kebudayaan No. 754/P/2020 tentang Indikator Kinerja Utama Perguruan Tinggi Negeri dan Lembaga Layanan Pendidikan Tinggi di Lingkungan Kementerian Pendidikan dan Kebudayaan tahun 2020. 